\title{
SISTEM PEMILIHAN PRESIDEN DI INDONESIA
}

\author{
NAMA \\ HURIA RIFDAH ROFFI \\ NIM \\ 2010003600041
}

\section{A. PENDAHULUAN}

Sebagaimana diketahui, Indonesia adalah salah satu negara yang menganut demokrasi sebagai sistem pemerintahannya. Jika merujuk pada sejarah-sejarah negara besar yang berjaya dengan konsep demokrasi serta pendahulu bangsa yang menggagas sistem pemerintahan, maka sistem pemerintahan demokrasi ini diyakini telah sesuai dengan karakter bangsa Indonesia yang toleran. Konsep pemerintahan demokrasi adalah pemerintahan dari rakyat, oleh rakyat dan untuk rakyat. Pasal 1 ayat (2) UUD NRI Tahun 1945 menegaskan bahwa kedaulatan berada di tangan rakyat dan dilaksanakan menurut Undang- Undang Dasar.

Adapun salah satu syarat pokok atau asas penyelenggaraan pemerintahan demokrasi di Indonesia adalah menyelenggarakan pemilihan umum (pemilu). Pemilihan umum atau pemilu adalah bentuk nyata dari konsep negara demokrasi itu sendiri. Dengan kata lain, pemilihan umum (pemilu) merupakan instrumen penting dalam negara demokrasi. Oleh karena itu, lazimnya di negara-negara yang menamakan diri sebagai negara demokrasi, termasuk Indonesia mentradisikan pemilu untuk memilih pejabat-pejabat publik di bidang legislatif dan eksekutif.

Berdasarkan ketentuan Undang-Undang Dasar Negara Republik Indonesia Tahun 1945 (UUD NRI Tahun 1945) Pasal 1 ayat (1): “Indonesia merupakan Negara Kesatuan yang berbentuk Republik". Sebagai Negara Republik, maka kekuasaan pemerintah di Indonesia dipimpin oleh seorang Presiden. Hal ini diatur dalam UUD NRI Tahun 1945 pasal 4 Ayat (1), 
dimana Presiden Republik Indonesia memegang kekuasaan pemerintahan menurut UndangUndang Dasar.

Berkaitan dengan penyelenggaraan pemilihan umum (Pemilu), mekanisme pemilihan Presiden sebagai pejabat eksekutif diatur secara lebih rinci dalam Pasal 6A UUD 1945, sedangkan Indonesia mengatur perihal pelaksanaan pemilu dalam pasal 22E UUD NRI Tahun 1945. Berangkat dari uraian tersebut, penulis tertarik untuk membahas lebih jauh mengenai sistem pemilihan Presiden di Indonesia.

\section{B. PEMBAHASAN}

Menurut ketentuan UUD NRI Tahun 1945, yang termasuk dalam pemilu adalah pemilihan anggota Dewan Perwakilan Rakyat (DPR), Dewan Perwakilan Daerah (DPD), Dewan Perwakilan Rakyat Daerah (DPRD) serta pemilihan Presiden dan Wakil Presiden. Berkaitan dengan penyelenggaraan pemilihan umum (Pemilu), mekanisme pemilihan Presiden sebagai pejabat eksekutif diatur secara lebih rinci dalam Pasal 6A UUD 1945.

Mekanisme pemilihan Presiden dan Wakil Presiden diatur secara lebih rinci dalam Pasal 6A UUD 1945 dijabarkan ke dalam lima ayat berikut:

(1) Presiden dan Wakil Presiden dipilih dalam satu pasangan secara langsung oleh rakyat.

(2) Pasangan calon Presiden dan Wakil Presiden diusulkan oleh partai politik atau gabungan partai politik peserta pemilihan umum sebelum pelaksanaan pemilihan umum.

(3) Pasangan calon Presiden dan Wakil Presiden yang mendapatkan suara lebih dari lima puluh persen dari jumlah suara dalam pemilihan umum dengan sedikitnya dua 
puluh persen suara di setiap provinsi yang tersebar di lebih dari setengah jumlah provinsi di Indonesia, dilantik menjadi Presiden dan Wakil Presiden.

(4) Dalam hal tidak ada pasangan calon Presiden dan Wakil Presiden terpilih, dua pasangan calon yang memperoleh suara terbanyak pertama dan kedua dalam pemilihan umum dipilih oleh rakyat secara langsung dan pasangan yang memperoleh suara rakyat terbanyak dilantik sebagai Presiden dan Wakil Presiden.

(5) Tata cara pelaksanaan pemilihan Presiden dan Wakil Presiden lebih lanjut diatur dalam undang-undang (UUD 1945).

Disahkannya Pasal 6A ayat (1) UUD 1945 ini secara otomatis mencabut kewenangan MPR-RI untuk memilih Presiden dan Wakil Presiden dan beralih pada ketentuan baru bahwa yang berwenang untuk memilih Presiden dan Wakil Presiden adalah hak rakyat Indonesia, oleh karena itu keterlibatan rakyat dan penguatan kedaulatan rakyat semakin diakui karena rakyat bisa secara langsung memilih pemimpin negaranya sendiri. Keterlibatan partai politik untuk mengajukan calon Presiden dan Wakil Presiden seperti yang diatur dalam Pasal 6A ayat (2) juga menjadi implikasi positif terhadap kedaulatan partai politik yang secara konstitusional diakui dalam sistem pemilihan kepala negara di Indonesia. Secara normatif, perkembangan sistem demokrasi di Indonesia sangat dipengaruhi oleh perubahan UUD NRI 1945 yang berkaitan dengan sistem pengisian jabatan Presiden dan Wakil Presiden ini, dimana rakyat diberikan peran yang besar dalam menentukan kebijakan-kebijakan nasional.

Dalam praktiknya selama ini, pemilihan anggota DPR, DPD dan DPRD ditempatkan secara terpisah dengan pemilihan Presiden dan Wakil Presiden dalam rezim pemilu legislatif. Sedangkan pemilihan Presiden dan Wakil Presiden ditempatkan dan diselenggarakan secara tersendiri dalam rezim pemilihan Presiden dan Wakil Presiden. Namun, setelah adanya 
Putusan Mahkamah Konstitusi Nomor 14/PUU-XI/2013 tentang Pengujian Undang-Undang Nomor 42 Tahun 2008 tentang Pemilihan Umum Presiden dan Wakil Presiden, lahir konsep pemilu serentak. Mahkamah Konstitusi dalam putusannya menyatakan bahwa penyelenggaraan pemilu legislatif dan pemilu Presiden dan Wakil Presiden diselenggarakan secara bersamaan yang berlaku pada pemilu 2019 dan pemilu seterusnya. Perlunya pemilu serentak merupakan hasil uji materi (judicial review) atas Undang-Undang No. 42 Tahun 2008 tentang Pemilihan Umum Presiden dan Wakil Presiden terhadap UUD NRI. Dengan demikian, dapat diketahui bahwa sistem pemilihan Presiden di Indonesia mulai tahun 2019 dan seterusnya dilakukan secara langsung oleh rakyat dan dilakukan secara serentak bersamaan dengan pemilu legislatif.

Dalam sistem pemilihan Presiden, juga diketahui bahwa untuk pengusungan calon Presiden harus memenuhi pensyaratan perolehan kursi minimal. Hal ini kemudian disebut sebagai ambang batas perolehan suara atau yang lebih dikenal dengan istilah threshold. Wahyudi dkk (2020) menyatakan bahwa perkembangan pemilihan umum dalam konsep demokrasi Indonesia, membawa threshold pada setiap sistem bentuk pemilihan umum, mulai dari electoral threshold seabagai syarat partai politik dapat ikut serta dalam Pemilu, parliementary threshold sebagai bentuk ambang batas partai untuk dapat menduduki kursi parlemen pusat, hingga presidential threshold sebagai ambang batas suara partai untuk mengusung calon Presiden dan Wakil Presiden dalam Pemilihan Umum. Jadi, dalam Pemilu di Indonesia, kata threshold dijumpai dalam tiga kasus pengaturan sistem Pemilu.

1. Pertama, electoral threshold tertuang dalam Pasal 39 UU Nomor 3 Tahun 1999 Tentang Pemilihan Umum. Ketentuan ini dicantumkan kembali pada Pasal 143 
ayat (1) UU Nomor 12 Tahun 2003 tentang pemilu Anggota DPR, DPD, dan DPRD.

2. Kedua, presidential threshold tertuang dalam Pasal 5 ayat (4) UU Nomor 23 Tahun 2003 tentang Pilpres, Pasal 9 UU Nomor 42 Tahun 2008 tentang Pemilu Pilpres dan kemudian diatur kembali dalam UU Nomor 7 Tahun 2017 tentang Pemilihan Umum.

3. Ketiga, parliamentary treshold tertuang dalam Pasal 202 ayat (1) UU Nomor 10 Tahun 2008 tentang Pemilu. Saat Pemilihan Umum 2014, dalam Undang-Undang Nomor 8 Tahun 2012 tentang Pemilu Legislatif.

Tujuan diadakannya ambang batas, yang dalam hal ini presidential threshold adalah untuk memperkuat sistem pemerintahan Presidensial atau membentuk sistem pemerintahan Presidensial yang efektif. Sebab Indonesia adalah negara yang menganut sistem pemerintahan Presidensial. Hal ini sebagaimana dikatakan oleh Sodikin (2014) bahwa pada awalnya pengaturan presidential threshold oleh pembentuk Undang-Undang adalah dalam rangka penguatan sistem presidensial.

Dalam Pasal 5 ayat (4) UU Nomor 23 Tahun 2003 tentang Pemilihan Umum Presiden dan Wakil Presiden disebutkan bahwa: "Pasangan Calon sebagaimana dimaksud pada ayat (1) hanya dapat diusulkan oleh partai politik atau gabungan partai politik yang memperoleh sekurang-kurangnya 15\% (lima belas persen) dari jumlah kursi DPR atau 20\% (dua puluh persen) dari perolehan suara sah secara nasional dalam Pemilu anggota DPR". Dengan demikian, Pasal 5 UU Nomor 23 Tahun 2013 ini mengatur tentang pasangan calon Presiden dan Wakil Presiden diajukan oleh partai atau gabungan partai yang memiliki sedikitnya 15 persen kursi DPR atau 20 persen suara Pemilu DPR. Ketentuan ini dinaikkan menjadi 20 
persen kursi DPR atau 25 persen suara Pemilu DPR oleh Pasal 9 UU Nomor 42 Tahun 2008 yang mengatakan: "Pasangan Calon diusulkan oleh Partai Politik atau Gabungan Partai Politik peserta Pemilu yang memenuhi persyaratan perolehan kursi paling sedikit $20 \%$ dari jumlah kursi DPR atau memperoleh 25\% dari suara sah nasional dalam Pemilu anggota DPR, sebelum pelaksanaan Pemilu Presiden dan Wakil Presiden." Aturan tentang Pemilu ini kemudian diatur kembali dalam UU Nomor 7 Tahun 2017 tentang Pemilihan umum. Inilah yang disebut presidential threshold, yaitu batas minimal perolehan kursi atau suara partai atau koalisi partai agar bisa mengajukan pasangan calon Presiden dan Wakil Presiden.

Namun demikian, pengaturan bagi calon Presiden yang harus memenuhi perolehan kursi minimal (ambang batas perolehan suara/threshold) dalam sistem pemilihan Presiden secara umum sulit diterima oleh sebagian Partai Politik karena membatasi dalam hal pengusungan bakal calon Presiden. Maka dari itu banyak pihak yang mengajukan gugatan ke Mahkamah Konstitusi (MK), baik itu orang pribadi maupun perwakilan partai. Dimana isi gugatan tersebut semuanya menuntut tentang pemberlakuan ambang batas/presidential threshold yang menimbulkan pelanggaran hak politik pribadi warga negara maupun partai poltik dan menuntut pernyataan bahwa pembuat UU telah salah membuat aturan lebih lanjut soal tata cara pelaksanaan pemilihan Presiden sebagaimana yang diamanatkan oleh pasal 6A UUD NRI 1945 dengan menambah syarat presidential threshold.

\section{PENUTUP}

Berdasarkan pembahasan pada artikel ini, dapat disimpulkan bahwa sistem pemilihan Presiden di Indonesia berdasarkan Pasal 6A ayat (1) UUD 1945 adalah tidak lagi menjadi kewenangan MPR-RI untuk memilih Presiden dan Wakil Presiden dan beralih pada ketentuan baru bahwa yang berwenang untuk memilih Presiden dan Wakil Presiden adalah hak rakyat 
Indonesia. Sebelumnya, pemilihan Presiden dan Wakil Presiden ditempatkan dan diselenggarakan secara tersendiri dalam rezim pemilihan Presiden dan Wakil Presiden dan terpisah dengan pemilihan anggota DPR, DPD dan DPRD. Namun semenjak adanya Putusan Mahkamah Konstitusi Nomor 14/PUU-XI/2013 tentang Pengujian Undang-Undang Nomor 42 Tahun 2008 tentang Pemilihan Umum Presiden dan Wakil Presiden, lahir konsep pemilu serentak. Kosep pemilu serentak ini diselenggarakan mulai tahun 2019 dan seterusnya. Dalam sistem pemilihan Presiden, juga diketahui bahwa untuk pengusungan calon Presiden harus memenuhi pensyaratan perolehan kursi minimal. Hal ini kemudian disebut sebagai ambang batas perolehan suara atau yang lebih dikenal dengan istilah threshold. Namun demikian, pengaturan bagi calon Presiden yang harus memenuhi perolehan kursi minimal (ambang batas perolehan suara/threshold) dalam sistem pemilihan Presiden secara umum sulit diterima oleh sebagian Partai Politik karena membatasi dalam hal pengusungan bakal calon Presiden.

\section{DAFTAR PUSTAKA}

Darmini Roza dan Laurensius Arliman S Peran Pemerintah Daerah Di Dalam Melindungi Hak Anak Di Indonesia, Masalah-Masalah Hukum, Volume 47, Nomor 1, 2018.

Laurensius Arliman S, Komnas HAM dan Perlindungan Anak Pelaku Tindak Pidana, Deepublish, Yogyakarta, 2015.

Laurensius Arliman S, Penguatan Perlindungan Anak Dari Tindakan Human Trafficking Di Daerah Perbatasan Indonesia, Jurnal Selat, Volume 4, Nomor 1, 2016.

Laurensius Arliman S, Problematika Dan Solusi Pemenuhan Perlindungan Hak Anak Sebagai Tersangka Tindak Pidana Di Satlantas Polresta Pariaman, Justicia Islamica, Volume 13, Nomor 2, 2016.

Laurensius Arliman S, Pelaksanaan Perlindungan Anak Yang Tereksploitasi Secara Ekonomi Oleh Pemerintah Kota Padang, Veritas et Justitia, Volume 2, Nomor 1, 2016.

Laurensius Arliman S, Kedudukan Ketetapan MPR Dalam Hierarki Peraturan PerundangUndangan Di Indonesia, Lex Jurnalica, Volume 13, Nomor 3, 2016. 
Laurensius Arliman S, Komnas Perempuan Sebagai State Auxialiary Bodies Dalam Penegakan Ham Perempuan Indonesia, Justicia Islamica, Volume 14, Nomor 2, 2017.

Laurensius Arliman S, Peranan Pers Untuk Mewujudkan Perlindungan Anak Berkelanjutan Di Indonesia, Jurnal Ilmu Hukum Tambun Bungai, Volume 2, Nomor 2, 2017.

Laurensius Arliman S, Mewujudkan Penegakan Hukum Yang Baik Untuk Mewujudkan Indonesia Sebagai Negara Hukum, Jurnal Hukum Doctrinal, Volume 2, Nomor 2, 2017.

Laurensius Arliman S, Participation Non-Governmental Organization In Protecting Child Rights In The Area Of Social Conflict, The 1st Ushuluddin and Islamic Thought International Conference (Usicon), Volume 1, 2017.

Laurensius Arliman S, Partisipasi Masyarakat Dalam Pembentukan Perundang-Undangan Untuk Mewujudkan Negara Kesejahteraan Indonesia, Jurnal Politik Pemerintahan Dharma Praja, Volume 10, Nomor 1, 2017, https://doi.org/10.33701/jppdp.v10i1.379.

Laurensius Arliman S, Peran Komisi Perlindungan Anak Indonesia Untuk Mewujudkan Perlindungan Anak, Jurnal Respublica Volume 17, Nomor 2, 2018.

Laurensius Arliman S, Menjerat Pelaku Penyuruh Pengrusakan Barang Milik Orang Lain Dengan Mempertimbangkan Asas Fungsi Sosial, Jurnal Gagasan Hukum, Volume 1, Nomor 1, 2019.

Laurensius Arliman S, Ilmu Perundang-Undangan Yang Baik Untuk Negara Indonesia, Deepublish, Yogyakarta, 2019.

Laurensius Arliman S, Isdal Veri, Gustiwarni, Elfitrayenti, Ade Sakurawati, Yasri, Pengaruh Karakteristik Individu, Perlindungan Hak Perempuan Terhadap Kualitas Pelayanan Komnas Perempuan Dengan Kompetensi Sumber Daya Manusia Sebagai Variabel Mediasi, Jurnal Menara Ekonomi: Penelitian dan Kajian Ilmiah Bidang Ekonomi, Volume 6, Nomor 2, 2020.

Laurensius Arliman S, Pendidikan Kewarganegaraan, Deepublish, Yogyakarta, 2020.

Laurensius Arliman S, Makna Keuangan Negara Dalam Pasal Pasal 23 E Undang-Undang Dasar 1945, Jurnal Lex Librum, Volume 6, Nomor 2 Juni 2020, http://dx.doi.org/10.46839/1ljih.v6i2.151.

Laurensius Arliman S, Kedudukan Lembaga Negara Independen Di Indonesia Untuk Mencapai Tujuan Negara Hukum, Kertha Semaya Journal Ilmu Hukum, Volume 8, Nomor 7, 2020. 
Laurensius Arliman S, Pelaksanaan Assesment Oleh Polres Kepulauan Mentawai Sebagai Bentuk Pelaksanaan Rehabilitasi Bagi Pecandu Dan Korban Penyalahgunaan Narkotika, Jurnal Muhakkamah, Volume 5, Nomor 1, 2020.

Laurensius Arliman S, Aswandi Aswandi, Firgi Nurdiansyah, Laxmy Defilah, Nova Sari Yudistia, Ni Putu Eka, Viona Putri, Zakia Zakia, Ernita Arief, Prinsip, Mekanisme Dan Bentuk Pelayanan Informasi Kepada Publik Oleh Direktorat Jenderal Pajak, Volume 17, No Nomor, 2020.

Larensius Arliman S, Koordinasi PT. Pegadaian (Persero) Dengan Direktorat Reserse Narkoba Polda Sumbar Dalam Penimbangan Barang Bukti Penyalahgunaan Narkotika, UIR Law Review, Volume 4, Nomor 2, 2020, https://doi.org/10.25299/uirlrev.2020.vol4(1).3779.

Laurensius Arliman S, Tantangan Pendidikan Kewarganegaraan Pada Revolusi 4.0, Ensiklopedia Sosial Review, Volume 2, Nomor 3, 2020.

Muhammad Afif dan Laurensius Arliman S, Protection Of Children's Rights Of The Islamic And Constitutional Law Perspective Of The Republic Of Indonesia, Proceeding: Internasional Conference On Humanity, Law And Sharia (Ichlash), Volume 1, Nomor 2,2020 .

Otong Rosadi danLaurensius Arliman S, Urgensi Pengaturan Badan Pembinaan Idelogi Pancasila Berdasarkan Undang-Undang Sebagai State Auxiliary Bodies yang Merawat Pancasila dalam Perspektif Hak Asasi Manusia, Prosiding Konferensi Nasional Hak Asasi Manusia, Kebudayaan dan Tujuan Pembangunan Berkelanjutan Indonesia pada Masa Pandemi Covid-19: Tantangan untuk Keilmuan Hukum dan Sosial Volume 1, Universitas Pancasila, Jakarta, 2020. 